\title{
Of Disputed Borders, Armed Conflict, Periodic Crises, and Regional Rivalry: The Past and the Future of Sino-Indian Relations
}

\author{
Sumit Ganguly
}

SHADOW STATES: India, China and the Himalayas, 1910-1962. By Bérénice Guyot-Réchard. Cambridge, UK; New York, NY: Cambridge University Press, 2016. xxv, 321 pp. (Maps, illustrations.) US\$99.99, cloth. ISBN 9781-107-17679-9.

INDIA TURNS EAST: International Engagement and US-China Rivalry. By Frédéric Grare. London, UK: C. Hurst E Company, 2017. ix, 265 pp. $£ 30.00$, cloth. ISBN 978-1-84904-835-4.

MUSLIM, TRADER, NOMAD, SPY: China's Cold War and the People of the Tibetan Borderlands. By Sulmaan Wasif Khan. Chapel Hill: University of North Carolina Press, 2016. 216 pp. (Maps.) US\$27.50, paper. ISBN 9781-4696-3075-5.

CHINA'S INDIA WAR: Collision Course on the Roof of the World. By Bertil Lintner. New York: Oxford University Press, 2018. US\$34.95, cloth. ISBN 978-0-19-947555-1.

\section{Abstract}

These four books on Sino-Indian relations provide new evidence and novel arguments about the origins of the border dispute, the Sino-Indian border war of 1962, and the evolution of the Sino-Indian rivalry. Three of the four books have made use of newly declassified archival material and have thereby challenged existing knowledge about various features of this contentious relationship. The books, nevertheless, are of varying quality. One or two of them represent the acme of dispassionate scholarship while at least one asserts some very partisan claims. That said, they all represent a new wave of scholarship on Sino-Indian relations and should be of value to those interested in this fraught relationship.

Keywords: Sino-Indian War of 1962, "Look East" policy, Himalayan states, Tibet, Mao-Tse-Tung, Mao Zedong, Jawaharlal Nehru, "forward policy"

DOI: $10.5509 / 2018913539$ 
$\mathrm{T}$ The two most populous states in the world share a border that is over four thousand kilometres long. This border, with the exception of a small segment, is the subject of a seemingly intractable dispute. The disagreement about the alignment of the border contributed to clashes in the late fifties and culminated in a brief but bitter border war in 1962. ${ }^{1}$ Subsequently, at least two border crises, in 1967 and 1986, have disrupted the countries' relations. In the wake of the border war, ambassadorial-level diplomatic relations were suspended and only resumed in $1976 .{ }^{2}$ Since 1981, there have been nineteen rounds of talks between officials of the two states. Despite a series of agreements, the most recent of which, the Border Defence and Cooperation Agreement (BDCA), was signed in 2013, the dispute is no closer to a resolution. Instead in July and August of 2017, military units from the two states were involved in an eyeball-to-eyeball confrontation on the Doklam Plateau near the Bhutan-Tibet-India tri-junction. By the end of August, the confrontation was over, but without a formal resolution of the casus belli.

Beyond the border issue, the contentious Sino-Indian relationship also has important regional ramifications as the two states are now locked into a profoundly competitive relationship within South Asia. Furthermore, their rivalry has also spilled over into the Indian Ocean region. ${ }^{3}$ It is also evident in their attempts to expand their influence in the Indo-Pacific.

What explains the inability of the two parties to resolve this dispute? After all, the People's Republic of China (PRC) has managed to settle a series of border disputes with a host of other states. ${ }^{4}$ Also, what explains the expansion of the rivalry into adjacent regions? Are the sources of the rivalry rooted in the domestic politics of the two states, in ideological competition, or are there structural origins? A number of works have previously addressed aspects of these questions. ${ }^{5}$

More recently, however, a series of books have not only uncovered new evidence on the origins of the territorial dispute but have also examined the role of external powers, and spillover into neighbouring regions. This essay

Sumit Ganguly is a Distinguished Professor of Political Science and holds the Tagore Chair in Indian Cultures and Civilizations at Indiana University, Bloomington. During the 2018-2019 academic year he is also an Alexander von Humboldt Fellow at Heidelberg University.

\footnotetext{
For a dispassionate analysis of the origins of the war see Steven Hoffman, India and the China Crisis (Berkeley: University of California Press, 1990).

2 B.M. Jain, "India-China Relations: Issues and Emerging Trends," The Round Table: The Commonwealth Journal of International Affairs 93, no. 374 (2004): 253-269.

David Brewster, "An Indian Ocean Dilemma: Sino-Indian Rivalry and China's Strategic Vulnerability in the Indian Ocean,” Journal of Indian Ocean Studies 11, no. 1 (2015): 48-59.

4 For a discussion of these settlements see M. Taylor Fravel, Strong Borders, Secure Nation: Cooperation and Conflict In China's Territorial Disputes (Princeton: Princeton University Press, 2008).

See for example, John W. Garver, Protracted Contest: Sino-Indian Rivalry in the Twentieth Century (Seattle: University of Washington Press, 2002).
} 
will evaluate the evidence that has been brought to bear, critique some of the arguments, and discuss new directions in the scholarship.

\section{From the Border Dispute to the Border War}

A substantial corpus of literature exists on the origins of the Sino-Indian border dispute as well as the border war. ${ }^{6}$ However, some of it is blatantly partisan. This is especially the case with much of the secondary work on the Sino-Indian border war. In considerable part the bias that characterizes the literature stems from Neville Maxwell's India's China War, an early account of the origins of the war. ${ }^{7}$ Maxwell squarely blamed the actions of the Jawaharlal Nehru government for the war. Specifically, he argued that India's adoption of the "forward policy" - a military strategy that in the words of an Indian general had "neither teeth nor tail" - was one of the principal precipitants of the conflict. There is little or no question that the policy was deeply flawed. It was a textbook case of "compellence failure": an attempt to undo what a perceived aggressor had done without possessing the requisite military capabilities to accomplish the task. ${ }^{8}$ However, as argued persuasively in one of the books under discussion, for all its tactical shortcomings the "forward policy" was most assuredly not the immediate stimulus for the Chinese attack. Instead it was merely the pretext for the well-orchestrated PLA attack on India's northern borders.

While assigning the blame for the war to India, Maxwell glossed over the brutality of the PRC's occupation of Tibet, its clandestine road-building activities in the Himalayas prior to the war, and its chicanery when Nehru first raised questions about various maps that depicted as Chinese significant chunks of territory that India deemed to be its own. Maxwell's book became received wisdom on the subject for an entire generation of scholars. Thus, subsequent scholarship that relied on his book reached some extremely dubious conclusions. ${ }^{9}$

Access to new archival evidence in India, the United Kingdom, and elsewhere has now contributed to a wave of scholarship on the border dispute and the Sino-Indian rivalry. Much of this scholarship upends previous work on the subject while some components of it are bound to stir new controversy. In this context, Berenice Guyot-Rechard's book, Shadow States: India, China

\footnotetext{
6 See for example, Margaret W. Fisher, Leo E. Rose, and R.A. Huttenback, Himalayan Battleground (London: Pall Mall, 1963); Alastair Lamb, The McMahon Line: A Study in the Relations between India, China and Tibet. 1904-1914 (London: Routledge and Kegan Paul, 1966); and John Rowland, A History of Sino-Indian Relations (Princeton: D. Van Nostrand Company, 1967). For a perspective from the PRC see Lui Xuecheng, The Sino-Indian Border Dispute and Sino-Indian Relations (Lanham: University Press of America, 1994).

$7 \quad$ Neville Maxwell, India's China War (New York: Pantheon Books, 1970).

8 For a discussion of the concept of "compellence" see Thomas Schelling, Arms and Influence (New Haven: Yale University Press, 2008).

9 See, for example, Allen S. Whiting, The Chinese Calculus of Deterrence: India and Indochina (Ann Arbor: University of Michigan Press, 1975).
} 
and the Himalayas, 1910-1962, must be considered a landmark study of the origins of the border dispute. The work, based on extensive archival research combined with a meticulous effort to comb through copious amounts of secondary scholarship, could well become the most invaluable resource for those interested in understanding the sources of this seemingly irresolvable conflict.

A novel and intriguing argument undergirds her work. She contends that both China and India came to adopt Westphalian conceptions of sovereignty following their emergence as independent states. This involved, among other matters, a quest for fixed and clearly delineated borders. This endeavour, while entirely understandable, was one of the principal reasons why the two states swiftly drifted into a confrontation along their Himalayan borders. The problem arose along this frontier because the inhabitants of these regions, especially in the eastern segment of the frontier, had not recognized the authority of particular sovereign entities for generations. Instead they had accepted the writ of local authorities and had deemed the boundaries of the areas that they lived in to be malleable. As Guyot-Rechard writes, "Neither the Qing nor the British empires, predecessors to today's China and India could boast of a concrete state presence in the eastern Himalayas" (12).

Even though she argues that her study is focused on developments on the ground, Guyot-Rechard aptly demonstrates how the ebb and flow of the high politics of both Qing China and British India induced them to expand their administrative reach over these areas, particularly in the eastern Himalayas. In turn, they sought to impose the writ on regions which had not previously paid suitable obeisance to the capitals of either state. Not surprisingly, these efforts called for appropriate cartographic demarcation, which invariably brought the two empires into conflict. ${ }^{10}$ These differences would come to the fore in the wake of the Communist revolution of 1949 in China and India's independence in 1947, as both new states sought to consolidate their respective standing in erstwhile fluid territories.

It is not easy to summarize in any detail the complex, competitive processes that unfolded between the two empires during the long period addressed by Guyot-Rechard. Instead a discussion of a few salient moments captures the crux of her argument. One of the initial sources of tension between the two empires stemmed from British fears of Qing expansionism along the frontier. This, in turn, led the British to steadily enhance their administrative presence in what was known as the North Eastern Frontier Agency (NEFA). It is important to note that even as China descended into civil war and turmoil from the late 1920s to the Communist victory in 1949, the forces of Chiang Kai-shek were discussing the significance of winning back China's "lost territories." These statements caused the British much anxiety and led them

10 For a discussion of these activities see Matthew H. Edeney, Mapping an Empire: The Geographic Construction of British India, 1765-1843 (Chicago: University of Chicago Press, 2009). 
to step up their activities in India's northeast. Such moves, at one level, were ironic because Chiang was a British ally during World War II.

The details of British attempts at expanding colonial administration into this region constitute much of her analysis. She also shows how these efforts generated counter reactions on the part of the Guomindang. Interestingly enough, in the $1950 \mathrm{~s}$, despite public professions of friendship and amity at diplomatic levels, both the successor states, China and India respectively, made arduous efforts to try and win the sympathies of the inhabitants of their respective border regions. As Guyot-Rechard writes, "Independence did not lead to the abandonment of imperial techniques and strategies in NEFA; on the contrary, they were crucial to the Nehruvian state's efforts to incorporate the region" (177). These efforts, almost invariably, put the two states on a collision course, especially following the Chinese invasion and occupation of Tibet.

India obviously lost the war and the outcome has proven to be quite traumatic for both the Indian political and military establishments. The memories of the defeat continue to animate Indian military planning and strategy. Despite India's military debacle and its consequent misgivings about Chinese strategic intentions, she argues that the PRC faces an uncertain future in Tibet. Years of repression and cooptation have not produced political order. ${ }^{11}$ India, for its part, continues to have its own problems of governance in the northeast and can only claim patchy progress in securing the loyalties of the inhabitants of the region. The only possible shortcoming of this otherwise excellent work is that its eventual discussion of India's and China's attempts to establish political order in their respective segments of this region is a little superficial. For a book that has laudable detail in its treatment of historical periods, the discussion of more recent political developments seems lacking in depth.

Another work that focuses on the fraught politics of this region is Sulmaan Wasif Khan's Muslim, Trader, Nomad, Spy: China's Cold War and the People of the Tibetan Borderlands. Khan's book offers some new evidence on the impact of the Cold War in this part of the world. However, it lacks the meticulous attention to evidence, both primary and secondary, that characterizes GuyotRechard's work. Instead it draws heavily from recently declassified PRC archives. Such reliance, on its own, should not constitute a significant drawback. However, the problem lies in his almost uncritical embrace of the PRC's positions on a series of highly contested and controversial subjects.

Additionally, the book is also hampered by another problematic feature. Considering that this is a work of historical scholarship, many sections rely on a rather anecdotal discourse rather than a careful analysis of the documentary record. Such a strategy may be appropriate in a work of popular

11 For a discussion of the concept of political order see Samuel Huntington, Political Order in Changing Societies (New Haven: Yale University Press, 1968). 
history but quite inapt for what purports to be a genuine historical analysis of a complex historical period.

A final shortcoming that mars this book is the lack of a central, undergirding thesis. There is no doubt that it deals with the politics of contested regions of the Himalayan frontier in the early Cold War years. However, beyond a focus on this contestation and an attempt to justify the choices of the PRC it is hard to discern a clearly articulated rationale for the work.

From the outset the author seeks to explain (and tacitly justify) the PRC's attempts to control (and subdue) Tibet. In fact, he is at pains to argue that the initial Chinese entry into Tibet was mostly a benign affair. To that end, he emphasizes the formal promises of fairness of treatment that Chinese leaders, especially Mao-Tse-Tung, had made to the Tibetans. These assurances, as scholars well know, were honoured in the breach. Monasteries were destroyed, Buddhist monks hounded and harassed, and the Tibetan population treated with much callousness if not outright brutality. ${ }^{12}$ Only in his discussion of the Khampa rebellion, which erupted in 1956, does Khan address the cruelty and harshness of the People's Liberation Army in dealing with the rebels.

His discussion of the Sino-Indian border differences is no better. For example, he uncritically trots out Premier Zhou-Enlai's offer to Prime Minister Nehru in 1960 to swap the region of Aksai Chin (which the PRC had laid claim to) in exchange for India's control of the North Eastern Frontier Agency. Quite apart from India having to supinely concede to the Chinese claim to the Aksai Chin, this offer came at a time when Nehru's room for political maneuver at home had all but closed. Significant border clashes had taken place between Indian and Chinese troops in 1959 and India's parliament was in an uproar over these episodes. More to the point, these protests were also the result of the obvious shortcomings of Nehru's prior efforts to placate the PRC through diplomatic efforts, his failure to disclose that the PLA had made incursions into areas that India deemed to be its own, and India's support for its seating in the United Nations Security Council.

Finally, the book has a somewhat disjointed and choppy quality to its organization. In considerable part this problem stems from the aforementioned lack of an overarching argument. Consequently, the latter sections of the book, which deal with the plight of some nomadic tribes that inhabited the frontier and found themselves caught between competing sovereign entities, are not explicitly linked with the early chapters dealing with Tibet.

The intensity of the Sino-Indian rivalry, of course, increased considerably

12 Tsering Sakya, The Dragon in the Land of Snows: A History of Modern Tibet Since 1947 (New York: Columbia University Press, 1947); also see Melvyn C. Goldstein, A History of Modern Tibet, 1913-1951: The Demise of the Lamaist State (Berkeley: University of California Press, 1991). 
after the 1962 border war. How this war came about is one of the key subjects addressed in Bertil Lintner's China's India War. As the very title suggests, Lintner's book argues that the PRC, not India, was responsible for initiating the 1962 conflict. In doing so he quite directly challenges those who have argued that Indian rigidity on the settlement of the border question, coupled with its adoption of the "forward policy," led to the war.

To that end, he constructs a plausible, if somewhat circumstantial, case that a combination of a drive to challenge India's leadership of the Third World as well as an opportunity to tackle domestic turmoil had led the PRC to launch the war against India in October 1962. His key argument is twofold. First, the PRC was unhappy with India's aspirations (and ability) to emerge as a leader of the postcolonial world and had wanted to use its military prowess to diminish India's evolving stature in the global arena. Consequently, after inflicting an unequivocal military defeat on India and firmly establishing control over the Aksai Chin (which enabled it to connect Tibet with the province of Xinjiang), it was content to withdraw from other areas that it had seized in the war.

Second, the conflict also stemmed from the imperatives of Chinese domestic politics. The disastrous domestic socio-economic consequences of Mao's "Great Leap Forward" policies, Lintner argues, had a considerable influence on the timing of the attack on India. The border war and its attendant propaganda enabled Mao to sideline powerful domestic opponents who had highlighted the abject failures of his ill-conceived scheme of backyard industrialization under the aegis of the policies of the "Great Leap Forward." ${ }^{13}$ Lintner also reveals that the PLA had carefully gathered evidence of India's military preparedness along the Himalayan border and was more than aware of its limitations. More to the point, it had carried out extensive preparations for a determined assault. Consequently, the popular belief that the Indian "forward policy" constituted the immediate precipitant of the war is actually little more than a partisan canard.

The evidence that Lintner has gathered to challenge some common and widespread assumptions about the origins of the war is impressive. However, he could have adduced more evidence when challenging the arguments of a pro-Chinese British historian, Alastair Lamb, on matters pertaining to the alignment of certain disputed Himalayan borders. Here Lintner relies mostly, if quite deftly, on secondary evidence. To firmly refute Lamb's claims it would have been helpful if Lintner could have produced new archival evidence.

Subsequent parts of his book turn to a discussion of the PRC's involvement in promoting internal discord in India through its support for Maoist movements, to the PRC's machinations to reduce India's influence in the

13 Frank Dikotter, Mao's Great Famine: The History of China's Most Devastating Catastrophe, 1958-62 (New York: Bloomsbury, 2010). 
Himalayan kingdoms of Bhutan and Nepal and finally in Burma (Myanmar). These are mostly quite straightforward but do offer some intriguing granular details of the PRC's attempts to undermine India's position in these states.

The books discussed so far in this essay focus mostly on the early years of the troubled Sino-Indian relationship. Frederic Grare's volume, India Turns East, however, deals with how the rivalry has now expanded in terms of its geographic scope. Previous scholarship, such as Isabelle Saint Mezard's excellent analysis, had primarily focused on the economic dimensions of India's "Look East" policy: an attempt to engage the states of Southeast Asia after a long period of considerable neglect. Grare, on the other hand, explicitly examines the strategic imperatives that have driven this turn eastward. ${ }^{14}$ In this context, he makes it abundantly clear that he believes the PRC's expanding reach into this region was a significant driver of India's shift in that direction in the 1990s.

In making the argument about the role of strategic competition as one of the key motivations underlying India's policy shift he does not dismiss the importance of economic considerations. However, he is at pains to stress that India's fitful embrace of more market-oriented policies in the early 1990s alone cannot adequately explain its decision to engage with the states of Southeast Asia.

Grare's book is superbly organized, well-argued and based on careful research. Given that he is dealing with a highly contemporaneous subject he has been unable to draw on archival sources. However, he has made extensive use of a range of sources that are available in the public domain. The book also demonstrates a very supple grasp of the pertinent secondary literature upon which Grare rests his analysis.

Grare deftly recapitulates the evolution of Sino-Indian relations over the past several decades and demonstrates how the PRC's growing capabilities and assertiveness pose both immediate and long-term threats to India's national security. In this discussion, he also shows how Pakistan, for all practical purposes, became a strategic surrogate for the PRC in South Asia. As a consequence, Indian security planners have to be acutely mindful of the implications of Sino-Pakistani strategic cooperation.

Most importantly, he highlights that Indian policy makers have yet to arrive at a clear consensus regarding how best to deal with the enhanced threats that the country faces from the PRC. In this context, he may have devoted some space to the abject lack of suitable policy expertise in India on the PRC and its adverse impact on the policy-making process. Given the security challenge that the PRC poses, the paucity of appropriate policyrelevant knowledge about the PRC is downright puzzling.

14 Isabelle Saint-Mezard, Eastward Bound: India's New Positioning in Asia (New Delhi: Manohar, 2006). 
The lack of a policy consensus about how best to deal with the threat from the PRC is also evident in India's relations with the United States. Grare quite accurately sums up the three strands of Indian views about this strategy. These range from a willingness to dovetail Indian policy with that of the United States, avoiding any such alignment, and finally pursuing a pragmatic strategic partnership without wholly embracing the American strategy.

His discussion of the origins of and India's reactions to the US "rebalancing" strategy toward Asia, which was undertaken during President Obama's second term, is quite supple. However, the entire discussion has recently been overtaken by events. It is far from self-evident that the Trump administration will sustain the key elements of that strategy. Indeed the Trump regime's entire policy orientation toward the region appears both incoherent and muddled, thereby leaving both allies and the principal likely adversary, the PRC, somewhat confused about what can reasonably be expected from the United States during his time in office. From the standpoint of policy makers in New Delhi, this is a matter of no minor concern, especially as the PRC has evinced no inclination to contain its footprint across much of the Indo-Pacific. On the contrary, it has ramped up its efforts to expand its influence, especially through the "belt and road" initiative, a series of infrastructural projects with significant strategic ramifications, designed to connect various parts of the PRC with a host of states in adjoining regions. ${ }^{15}$ The most troubling component of the initiative, from the standpoint of New Delhi, is obviously the China-Pakistan Economic Corridor (CPEC), which is expected to pass through disputed territory in the state of Jammu and Kashmir. ${ }^{16}$

Another important facet of the book that deserves comment is Grare's thoughtful exposition of a number of other key relationships that India has sought to forge in the recent past, as it attempts to cope with the PRC's rising profile in Southeast Asia. Accordingly, Grare dwells on India's ties with a number of states in the Indo-Pacific but very specifically with Burma (Myanmar), Australia, and Japan. His discussion of the evolution of India's ties with each of these states is quite robust and nuanced, even if some of the material he covers is familiar to specialists on the subject.

All these books, to varying degrees, have yielded new evidence and provided novel analytic perspectives on various aspects of the Sino-Indian rivalry. None, however, have any explicit theoretical assumptions guiding their analyses. That said, the books by Grare and Lintner have an implicit theoretical postulate: namely, that the roots of the Sino-Indian rivalry are mostly structural. The two states are both large, they have divergent self-

15 Tom Phillips, “The $\$ 900$ billion question: What is the Belt and Road initiative?” The Guardian, 11 May 2017.

16 Adrija Roychowdhury, "CPEC: The bumpy new trade route between China and Pakistan," The Indian Express, 16 May 2017. 
images, they have long vied for leadership within Asia and beyond, and they share a common disputed border. It is therefore hardly surprising that the rivalry has actually intensified as economic growth and concomitantly military capabilities have increased. Beyond the structural factors that have driven the rivalry, the emergence of particular regimes, the rise of specific personalities to positions of leadership, and domestic politics in both states have also affected the course of the relationship. ${ }^{17}$

The extant literature on rivalries in the field of international politics suggests a number of possible pathways for the ending of a rivalry. Some end in the military (or political) victory of one state, others end because domestic circumstances in one or both states contribute to a rapprochement, while still others conclude because one state simply concedes defeat. ${ }^{18}$ In the SinoIndian context none of these venues for rivalry termination seem likely at least in the foreseeable future. Consequently, how this rivalry evolves in the coming decades will, in considerable measure, determine the political and strategic landscape of Asia in the coming decades.

Indiana University, Bloomington, USA, December 2017

17 On this point see Manjeet S. Pardesi, "Instability in Tibet and the Sino-Indian Strategic Rivalry: Do Domestic Politics Matter?" in Asian Rivalries: Conflict, Escalation, and Limitations on Two-Level Games, eds. Sumit Ganguly and William R. Thompson (Palo Alto: Stanford University Press, 2011).

${ }_{18}$ Karen Rasler, William R. Thompson, and Sumit Ganguly, How Rivalries End (Philadelphia: University of Pennsylvania Press, 2013). 